\title{
Herbivory-induced plant volatiles from Oryza sativa and their influence on chemotaxis behaviour of Tibraca limbativentris stal. (Hemiptera: Pentatomidae) and egg parasitoids
}

\author{
R.C. Melo Machado" ${ }^{1}$, J. Sant'Ana ${ }^{1 *}$, \\ M.C. Blassioli-Moraes ${ }^{2}$, R.A. Laumann ${ }^{2}$ and M. Borges ${ }^{2}$ \\ ${ }^{1}$ Departamento de Fitossanidade, Faculdade de Agronomia, Universidade \\ Federal do Rio Grande do Sul, Porto Alegre, Brazil: ${ }^{2}$ Embrapa Recursos \\ Genéticos e Biotecnologia, Brasília, Brazil
}

\begin{abstract}
The rice stem bug, Tibraca limbativentris Stal. (Hemiptera: Pentatomidae) is one of the most important pests of rice crops, especially irrigated crops. Plant defence strategies against these bugs may involve the emission of chemical compounds, which are released following herbivore attacks, directly or indirectly harming pest performance. The aim of this study was to evaluate the influence of constitutive and herbivory-induced volatiles from rice plants (Oryza sativa L.) on the behavioural responses of $T$. limbativentris adults and egg parasitoids Trissolcus basalis (Wollaston) and Telenomus podisi (Ashmead) (Hymenoptera, Platygastridae). Plant volatiles were collected from undamaged plants of the rice cultivar IRGA 424 and from plants that suffered herbivory by five males or five females of $T$. limbativentris. Air-entrainment extracts were analysed by GC-flame ionization detector and GC-MS, and insect responses evaluated in a ' $\mathrm{Y}$ ' olfactometer. T. limbativentris feeding damaged on rice plants induced the release of 16 volatiles compounds in a higher amounts compared to undamaged plants The main compounds induced were $(E)$-2-hexenal, (E)-2-octen-1-ol, methyl salicylate and $\alpha$-muurolene. Female bugs were significantly attracted to air-entrainment extracts containing volatiles from undamaged plants compared with air-entrainment extracts containing volatiles emitted from plants damaged by T. limbativentris, whereas males showed no preference. Telenomus podisi females were significantly attracted to volatiles from air-entrainment extracts of plants damaged by females, whereas $T$. basalis showed no preference. These results suggest that rice plants may be emitting defence compounds, which could be avoided by $T$. limbativentris females and also acted indirectly by attracting natural enemies.
\end{abstract}

Keywords: rice plants, stink bug, Trissolcus basalis, Telenomus podisi, semiochemical, kairomone

*Author for correspondence

Phone: + 5551 3308-7414

Fax: + 5551 3308-6015

E-mail: josue.santana@ufrgs.br 


\section{Introduction}

Plants have developed several mechanisms to defend themselves against herbivores, microbial pathogens, and abiotic stress (Price et al., 1980; Turlings et al., 1990; Vet \& Dicke, 1992; Dicke, 1994; De Moraes et al., 1998; Turlings et al., 1998; Dicke \& Van Loon, 2000; De Moraes et al., 2001; Hoballah \& Turlings, 2001; Kessler \& Baldwin, 2001, 2002; Kessler et al., 2004; Dudareva et al., 2009; Mazid et al., 2011). These defences may involve non-volatile and volatile compounds derived from the secondary metabolism, which can act directly on herbivores as deterrent, repellent, or toxic substances, or indirectly, as cues for natural enemies of the herbivore to locate their hosts, respectively (Dicke, 1994; De Moraes et al., 1998; Turlings et al., 1998; Dicke \& Van Loon, 2000; Colazza et al., 2004a; Moraes et al., 2005, 2009; Heil, 2010). Volatile compounds induced by herbivory and involved in the chemical defence of plants are called herbivore-induced plant volatiles (HIPVs). The majority of these compounds are green leaf volatiles, i.e., $\mathrm{C}_{6}$ compounds, aldehydes, alcohols and esters, terpenoids and aromatics derived from the shikimic acid pathway (Halitschke et al., 2008; Arimura et al., 2009). Damage by the brown stink bug, Euchistus heros (Fabricius) (Hemiptera: Pentatomidae) induces the release of a blend of volatile compounds that attracts the bug's natural enemy, Telenomus podisi. The main herbivore-induced volatiles released by soybean are methyl salicylate, $(3 E, 7 E)-4,8,1$ 2 trimethyl-1,3,7,11 tridecatetraene, $(E, E)$ - $\alpha$-farnesene, $(E)-2-$ octen-1-ol (Moraes et al., 2005; Michereff et al., 2011). Induced defences and the blend of released volatiles depends on plant traits that vary among species or genotypes, i.e., natural enemies may respond to one cultivar damaged by an herbivore but not to a different cultivar injured by the same phytophagous insect (Dicke, 1999; Lin et al., 2008; Rasmann \& Turlings, 2008; Michereff et al., 2011). Another study showed that the natural enemy Trissolcus basalis responded to Vicia faba L. plants that were damaged by both herbivory and oviposition of the green stink bug Nezara viridula (L.) (Hemiptera: Pentatomidae), but did not respond to plants with just one type of damage (Colazza et al., 2004a). The main compound involved in the response of this natural enemy appears to be the sesquiterpene (E)- $\beta$-caryophyllene (Colazza et al., 2004b). In addition, the chemical profile emitted by herbivory or oviposition-damaged plants can be markedly different from those emitted by undamaged and mechanically damaged plants (De Moraes et al., 1998; Dicke \& Van Loon, 2000; Kessler \& Baldwin, 2001; Moraes et al., 2005, 2008a; Michereff, 2011). Several authors have proposed using plants' 'call for help' strategies in crop systems to manage pests and their natural enemies (Colazza et al., 2004a, b; Moraes et al., 2005, 2009; Heil, 2010; Blassioli-Moraes et al., 2013). HIPVs could be used in different contexts, including cultivating live plants that release volatiles that attract natural enemies (e.g., push-pull systems), breeding plants that release specific volatiles to manage natural enemies or repel pests (Cook et al., 2007) or direct application (spraying or use of slow release dispensers) of synthetic compounds to attract natural enemies (James, 2003, 2005; D'Alessandro \& Turlings, 2005; Conti \& Colazza, 2012; Kaplan, 2012).

One of the main rice pests in Brazil is the brown stalk stink bug, Tibraca limbativentris Stal. (Hemiptera: Pentatomidae), which is especially important in irrigated rice crops (Martins et al., 2009; SOSBAI, 2012). This stink bug has important natural enemies, such as the egg parasitoids T. podisi and
Trissolcus urichi (Maciel et al., 2007; Riffel et al., 2010), but there is no information about the chemical communication involved in this tritrophic interaction between the plant, its herbivore and the herbivore's natural enemy. This study aimed to understand the influence of Oryza sativa volatiles, induced by herbivory of $T$. limbativentris on the host searching behaviour of the brown stalk stink bug and two different parasitoids, T. podisi, known as T. limbativentris natural enemy (Maciel et al., 2007; Riffel et al., 2010) and T. basalis, not registered to this species.

\section{Materials and methods}

Plant cultivation and treatments

Rice (cultivar IRGA-417) seeds were cultivated using an organic substrate (Plantmax treated with NPK 5-20-20) in plastic plots of $500 \mathrm{ml}$. The plants were kept in a greenhouse and received water daily. They were $20 \mathrm{~cm}$ tall after 28-30 days of growth (V8 stage) (SOSBAI, 2012).

\section{Insect cultures}

Tibraca limbativentris individuals were obtained from a laboratory colony started from adults collected in rice fields in Eldorado do Sul, Rio Grande do Sul ( $30^{\circ} 02^{\prime} S$; $\left.51^{\circ} 23^{\prime} \mathrm{WGR}\right)$, Brazil. Bugs were reared in a controlled environment at L16:D8 photoperiod, $25 \pm 1{ }^{\circ} \mathrm{C}$ and $60 \pm 10 \%$ relative humidity (RH) in 21 plastic containers made from soft drink bottles, on a diet of rice plants from 30 to 60 days old (O. sativa-cultivar IRGA-417), which was also used by insects as a substrate for egg-laying. The food supply was renewed once a week. The first instar insects were reared in Gerbox-type boxes $(11 \times 11 \times 3 \mathrm{~cm})$ covered with filter paper $\left(80 \mathrm{~g} \mathrm{~m}^{-2}\right.$ grammature, $205 \mu \mathrm{m}$ thick, $14 \mu \mathrm{m}$ average pore Qualy J Lab Pro), on a diet of Ligustrum lucidum Ait. and green beans (Phaseolus vulgaris). The food supply was renewed once a week.

Eggs of $N$. viridula and E. heros parasitized by T. basalis and T. podisi, respectively, were obtained from the Brazilian Agricultural Research Corporation - Soybean, in Londrina, Paraná. The eggs were kept in a controlled environment at L14: D10 photoperiod, $21 \pm 1^{\circ} \mathrm{C}$ and $60 \pm 10 \mathrm{RH}$ until hatched. The wasps were maintained in $500 \mathrm{ml}$ PET bottle cages and fed with a drop of honey, supplied twice a week. The 2-3-day-old naïve females were used in the experiments.

\section{Plant volatile collection system}

To identify the chemical profiles of herbivory-damaged and undamaged rice plants (cv IRGA-417), the following treatments were used: (1) rice plants damaged by female stink bugs: five $T$. limbativentris female insects were placed on the plant; (2) plants damaged by male stink bugs: five T. limbativentris male insects were placed on the plant; and (3) a control with undamaged rice plants. All insects were 30 days old, at most, and mated before the experiment. No oviposition was observed during plant volatile collections. Each plant was placed in an individual glass chamber of 101 and the pots were wrapped in aluminium foil to minimize contamination by volatiles from the soil. Volatiles were collected each $24 \mathrm{~h}$, during five consecutive days, with nine replicates for each treatment. A glass tube containing the adsorbent Super Q (100 mg, 80-100 mesh, Alltech PA, USA) was connected via a PTFE tube to a vacuum pump at a flow of $0.61 \mathrm{~min}^{-1}$ and the air entrance was connected to a flow of air 
filtered with activated charcoal $\left(1.01 \mathrm{~min}^{-1}\right)$ creating a positive push-pull system (Moraes et al., 2008a). Trapped volatiles were eluted from the adsorbent using $500 \mu \mathrm{l} n$-hexane and preconcentrated to $100 \mu \mathrm{l}$ under a $\mathrm{N}_{2}$ flow. Extracts were stored at $-20^{\circ} \mathrm{C}$ until be used in chemical analysis and bioassays.

\section{$Y$-tube olfactometer and bioassay procedure}

To evaluate the response of male and female T. limbativentris to air-entrainment extracts obtained from the rice plants submitted to the different treatments described above, bioassays were carried out using a Y-olfactometer in plural experimental days. The responses of males and females, individually, were evaluated for virgin insects 15-30 days old after the final moult. All insects were placed in individual Gerbox boxes and kept separately without food for $24 \mathrm{~h}$ before the bioassays. Behaviour was observed in a Y-olfactometer ( $17 \mathrm{~cm}$ common tube, $22 \mathrm{~cm}$ arms, and $4 \mathrm{~cm}$ internal diameter). An aliquot of the extracts $(20 \mu \mathrm{l})$ was applied on pieces $(1.5 \times 1.2 \mathrm{~cm})$ of filter paper $\left(80 \mathrm{~g} \mathrm{~m}^{-2}\right.$ grammature, $205 \mu \mathrm{m}$ thick, $14 \mu \mathrm{m}$ average pore Qualy J Lab Pro), which remained at room temperature for $1 \mathrm{~min}$ before being inserted into the olfactometer arm, thus allowing the evaporation of the solvent. The insects were placed, individually, in the common tube and their choices observed during $15 \mathrm{~min}$.

The chemotaxis behaviour of 2-6-day-old T. podisi and T. basalis females was evaluated in a Y-olfactometer $(15 \mathrm{~cm}$ common tube, $17 \mathrm{~cm}$ arms, and $1 \mathrm{~cm}$ internal diameter). Females were placed, individually, in the common tube and their choices observed during $10 \mathrm{~min}$. The treatments $(10 \mu \mathrm{l})$ were applied on pieces $(1.0 \times 6.0 \mathrm{~cm})$ of filter paper, as described above, following the same procedure for the stink bug bioassays.

Stink bugs were presented with a choice between an aliquot of $20 \mu \mathrm{l}$ of air-entrainment extracts from plant damaged by female ( $N=76$, females and $N=77$, males) and by male ( $N=83$, females and $N=72$, males) collected after $24 \mathrm{~h}$ of damage versus $20 \mu \mathrm{l}$ of air-entrainment extracts from undamaged plants collected at the same condition. Parasitoids were exposed to air-entrainment extracts from plant damaged by female $(N=40, T$. podisi and $N=30, T$. basalis $)$ and male $(N=38$, $T$. podisi and $N=30, T$. basalis) collected after $24 \mathrm{~h}$ of damage versus volatiles from air-entrainment extracts from undamaged plants, as well as volatiles from air-entrainment extracts from undamaged plants versus $n$-hexane $(N=30$, $T$. podisi and $N=30, T$. basalis). All bioassays were conducted in an acclimatized room $\left(25 \pm 1^{\circ} \mathrm{C}\right.$ and $\left.60 \pm 10 \% \mathrm{RH}\right)$ during the photophase period and under fluorescent lights $(60 \mathrm{~W}$, luminance $=290$ lux). Air was conducted into the Y-olfactometer at $0.81 \mathrm{~min}^{-1}$. To avoid any bias in the insects responses, the arms through containing the control and treatment odours were inverted every three bioassays. The apparatus was cleaned after six bioassays with fragrance-free liquid soap, rinsed thoroughly with water followed by $n$-hexane and dried in a convection oven at $150^{\circ} \mathrm{C}$.

A single insect was introduced at the base of the Y-tube olfactometer, observed for $10 \mathrm{~min}$ and recorded the first choice in each arm. Stink bugs and parasitoids that moved at least $4 \mathrm{~cm}$ into one arm of the Y-tube for stink bugs and $2 \mathrm{~cm}$ for parasitoids, and remained there for at least $60 \mathrm{~s}$ were recorded as making a choice. If no choice was made in $10 \mathrm{~min}$, the assay was concluded and the insect considered non-responsive.

\section{Chemical analysis}

For quantification analysis, the extracts obtained by air entrainment were analysed by GC with a flame ionization detector (FID) at $270^{\circ} \mathrm{C}$ (Shimadzu 17A, DB-5 column, $30 \mathrm{~m} \times 0.25 \mathrm{~mm}$ ID, $0.25 \mu \mathrm{m}$ film, J\&W Scientific, Folsom, CA, USA), using a temperature program of $50^{\circ} \mathrm{C} / 1 \mathrm{~min}$, then $5^{\circ} \mathrm{Cmin}^{-1}$ to $180^{\circ} \mathrm{C} / 0.1 \mathrm{~min}$, then $10^{\circ} \mathrm{Cmin}^{-1}$ to $250^{\circ} \mathrm{C} /$ $20 \mathrm{~min}$. An aliquot of $20 \mu \mathrm{l}$ of each extract was separated and $2 \mu \mathrm{l}$ of tetracosane was added as an internal standard (IS), for a final concentration of $9.9 \mu \mathrm{g} \mathrm{ml}^{-1}$ of the IS. One microlitre of each sample was injected using a splitless mode with helium as the carrier gas. Amounts released by the plant in each $24 \mathrm{~h}$ period were calculated in relation to the area of the IS. Data were collected with ClassGC software and stored in Excel (Microsoft Corporation 2003). The other $80 \mu \mathrm{l}$ of the airentrainment extracts were mixed with $100 \mu$ l of $n$-hexane and the extracts kept at $-20^{\circ} \mathrm{C}$ until their use in the bioassays.

For qualitative analysis, selected extracts were analysed using a Shimadzu QP2010 instrument equipped with a quadrupole analyser, a non-polar DB- 5 column $(30 \mathrm{~m} \times 0.25 \mathrm{~mm}$ ID, $0.25 \mu \mathrm{m}$ film, J\&W Scientific, Folsom, CA, USA) and a splitless injector, with helium as the carrier gas. Ionization was by electron impact $\left(70-\mathrm{eV}\right.$, source temperature $\left.200^{\circ} \mathrm{C}\right)$. Data were collected and analysed with GC-MS Solutions 2.4 Software (Shimadzu Corporation, Japan). Identifications were made by comparing spectra with library databases (NIST 2005) or with published spectra and confirmed using retention index and with authentic standards when available.

\section{Chemical}

Super Q (80/100 mesh) was purchased from Alltech (PA, USA), $n$-hexane ( $95 \%$ pesticide residue) from Fisher Scientific (Loughborough, Leicestershire, UK), (E)-2-hexenal from Sigma Aldrich (Gillinghan, Dorset, UK), $\beta$-bisabolene and linalool from TCI America (Portland, USA). Methyl salicylate, 6-methyl-5-hepten-2-one, octanal, (E)-2-octen-1-ol, nonanal, decanal, geranylacetone and benzothiazole were purchased from Sigma Aldrich (Steinheim, Germany). $\alpha$-Curcumene, $\beta$-sesquiphellandrene and $\alpha$-zingiberene were provided by Jocelyn Millar (UCLA-Riverside, USA).

\section{Statistical analysis}

The total amount of released volatiles from each treatment over time was compared using a General Linear Model GLM and Deviance Analyses with gamma distribution and inverse as link function using the software R 2.14.1 (R Development Core Team, 2012). When the analyses showed significant effects of the treatments, means were compared using contrast analyses. The data from individual compounds neither follow a normal nor gamma distribution, thus the differences of the amounts of each individual compound between treatments were individually compared by nonparametric univariate statistics using Kruskal-Wallis test and submitted to Dunn test with $95 \%$ confidence level. The null hypothesis of equal preference (50\% first choice to each odour) of parasitoids and stink bugs in the Y-olfactometer bioassays was tested using $\chi^{2}$ tests $(P=0.05)$. Both tests were performed in Bioestat ${ }^{\circledR}$ 5.0 software. 


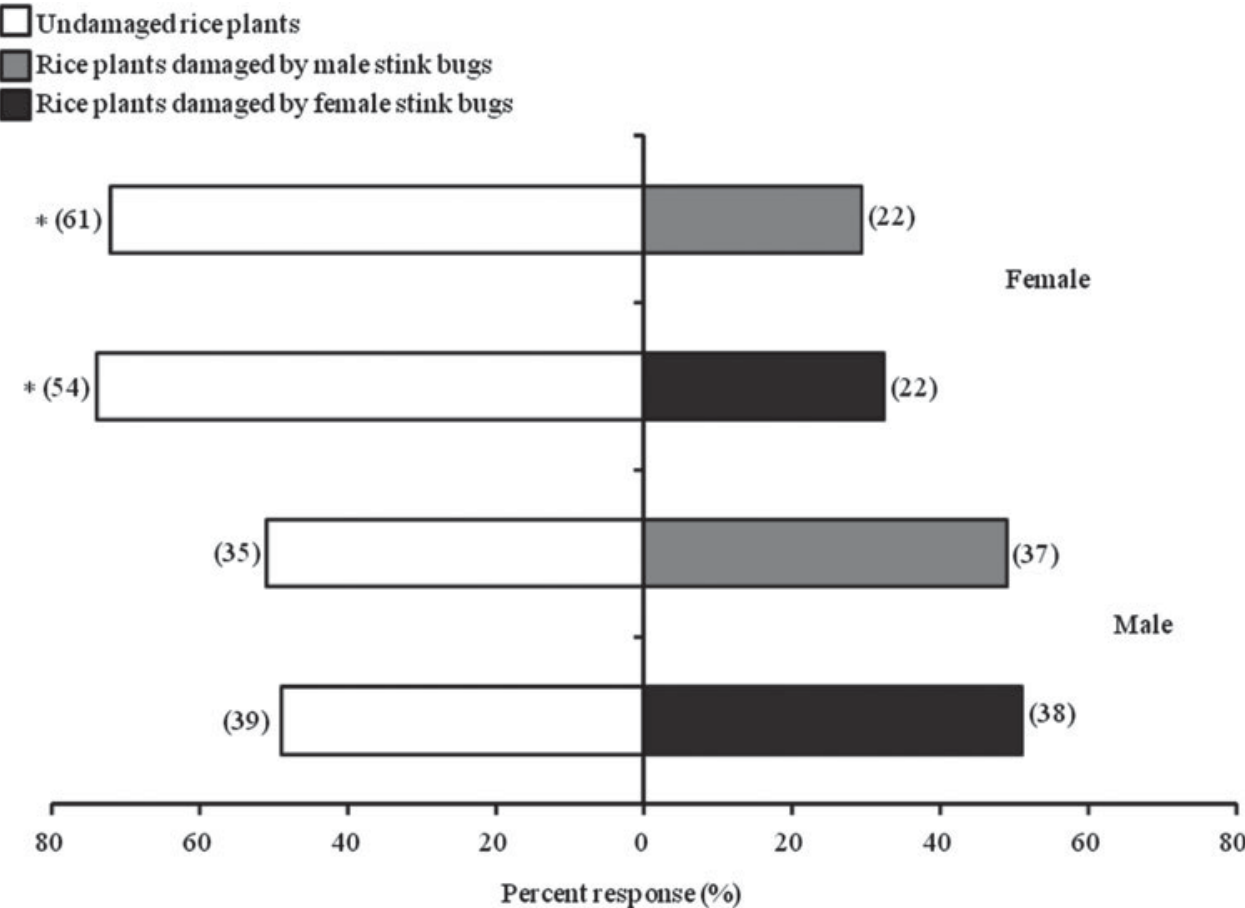

Fig. 1. Response (\% of tested insects) of male and female Tibraca limbativentris to extracts of plants (Oryza sativa) damaged by male and female conspecific herbivory. *Significantly different according to a $\chi^{2}$ test $(P<0.05)$. Numbers in brackets represent the number of responsive insects.

\section{Results}

\section{Tibraca limbativentris Y-tube olfactometer bioassays}

Rice stem bug females preferred volatiles obtained from air-entrainment extracts of undamaged plants compared to volatiles obtained from air-entrainment extracts of rice plants damaged by male $\left(\chi^{2}=36.65, P<0.001\right)$ and female $\left(\chi^{2}=26.94\right.$, $P<0.001$ ) (fig. 1). Males did not show a preference for any of these treatments $(P>0.05)$ (fig. 1$)$.

\section{Parasitoid Y-tube olfactometer bioassays}

Telenomus podisi females were more attracted to volatiles obtained from air-entrainment extracts of rice plants damaged by female stink bugs then those obtained from undamaged plants $\left(\chi^{2}=7.20, P=0.014\right)$. No such preference was observed for air-entrainment extracts of rice plants damaged by male stink bugs $\left(\chi^{2}=3.36, P=0.108\right)$ (fig. 2$)$. Telenomus podisi females also preferred undamaged plants compared to $n$-hexane $\left(\chi^{2}=7.14, P=0.016\right)$ (fig. 2).

In contrast, T. basalis did not prefer volatiles obtained from air-entrainment extracts of damaged or undamaged plants by both genders of $T$. limbativentris $\left(\chi^{2}=4.26 ; P=0.071\right)$ (fig. 3). However, they preferred volatiles obtained from air-entrainment extracts of undamaged plants to $n$-hexane $\left(\chi^{2}=7.69\right.$; $P=0.006$ ) (fig. 3).

\section{Chemical analysis}

The total amount of volatiles produced by rice plants differed between treatments (ANODEV; $\chi^{2}=16.87 ; \mathrm{df}=2$;
$P<0.001$ ), but did not change, in the same treatment, along the time (ANODEV; $\chi^{2}=0.0030 ; \mathrm{df}=2 ; P=0.95$ ). A contrast analysis showed that the total amount of volatiles from undamaged rice was marginal different from those emitted by female herbivory-damaged plants $(t=1.89, \mathrm{df}=97.2$, $P=0.06)$, but did not differ from those emitted by plants fed by males $(t=0.89, \mathrm{df}=97.2, P=0.42)$. There was no difference between the total amount of volatiles released by males and females herbivory plants $(t=1.73, \mathrm{df}=97.2, P=0.09)$ (fig. 4 ).

Considering the compounds individually there were quantitative differences between undamaged and damaged plants without considering the time (Kruskal-Wallis, $P<0.05$ ) (Table 1). The compounds $(E)-2$-hexenal $(H=15.11 ; \mathrm{df}=2$; $P<0.05)$, octanal $(H=19.55 ; \mathrm{df}=2 ; P<0.05)$, and decanal $(H=22.22 ; \mathrm{df}=2 ; P<0.05)$, the ketones 6-methyl-5-hepten-2one $(H=13.26 ; \mathrm{df}=2 ; P<0.05)$ and $(E, E)$-3,5-octadien-2-one $(H=10.13 ; \mathrm{df}=2 ; P>0.05)$, and the terpenoids $\beta$-sesquiphellandrene $(H=30.53 ; \mathrm{df}=2 ; P<0.05)$ and $\alpha$-muurolene $(H=11.06$; $\mathrm{df}=2 ; P<0.05)$ were released in greater amounts by rice plants damaged by $T$. limbativentris males and females than by undamaged plants (Table 1). In addition to these compounds, rice plants damaged by female $T$. limbativentris also released greater amounts of the following compounds than undamaged rice plants: linalool $(H=11.10 ; \mathrm{df}=2$; $P<0.05)$, $\alpha$-zingeberene $(H=10.39 ; \mathrm{df}=2 ; P<0.05)$, $\beta$-bisabolene $(H=6.90 ; \mathrm{df}=2 ; P<0.05), \beta$-cubebene $(H=6.97 ; \mathrm{df}=2$; $P<0.05)$ e $\alpha$-curcumene $(H=8.45 ; \mathrm{df}=2 ; P<0.05),(E)$-2-octen1-ol $(H=6.80 ; \mathrm{df}=2 ; P<0.05)$, benzothiazole $(H=12.53 ; \mathrm{df}=2$; $P<0.05)$, nonanal $(H=8.81 ; \mathrm{df}=2 ; P<0.05)$, methyl salicylate $(H=6.10 ; \mathrm{df}=2 ; P<0.05)$, and geranylacetone $(H=6.48 ; \mathrm{df}=2$; $P<0.05)$. 
$\square$ Undamaged rice plants

Rice plants damaged by female stink bugs

$\square$ Rice plants damaged by male stink bugs

$\square$ n-hexane

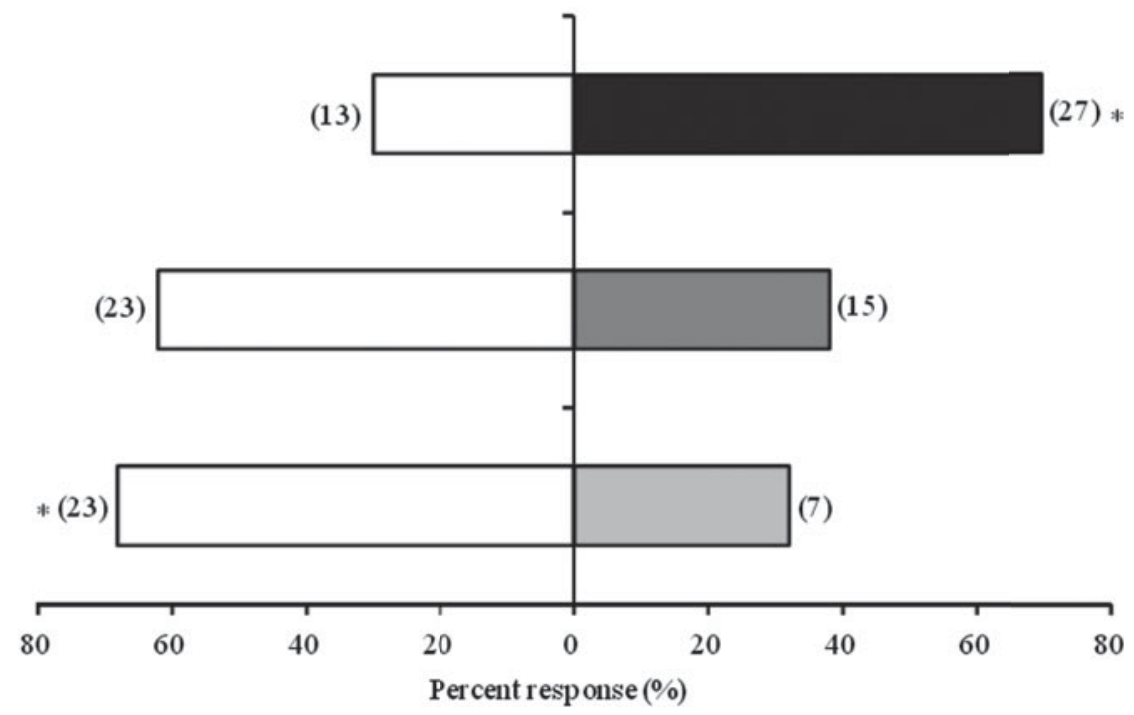

Fig. 2. Response (\% of tested insects) of Telenomus podisi females to extracts of plants (Oryza sativa) damaged by herbivory by both genders of Tibraca limbativentris. *Significantly different according to a $\chi^{2}$ test $(P<0.05)$. Numbers in brackets represent the number of responsive insects.

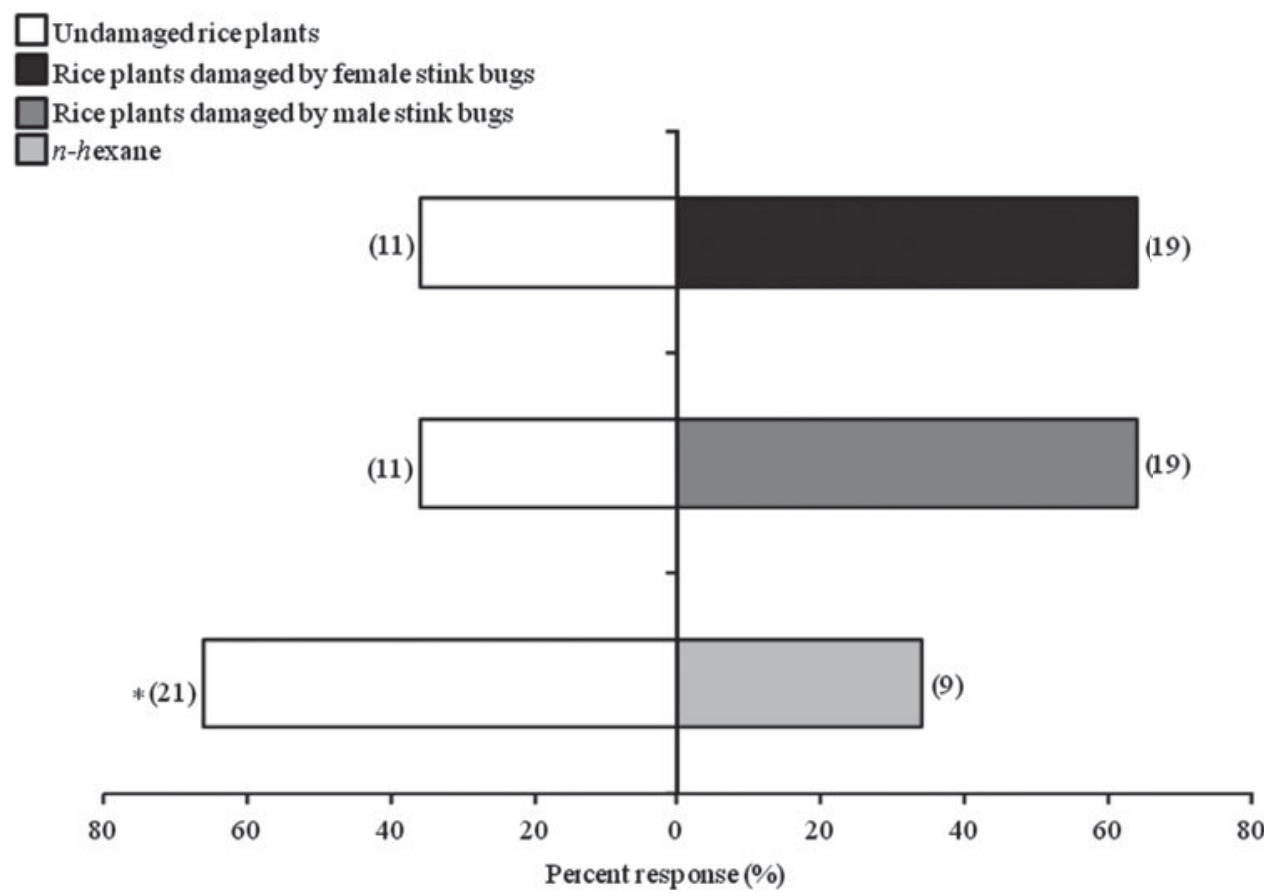

Fig. 3. Response (\% of tested insects) of Trissolcus basalis females to extracts of plants (Oryza sativa) damaged by herbivory by both genders of Tibraca limbativentris. ${ }^{*} \chi^{2}$ test $(P<0.05)$. Numbers in brackets represent the number of responsive insects. 
Table 1. Mean $( \pm$ SE) (ng/24h spanning from 24 to $120 \mathrm{~h})$ of volatile compounds collected from undamaged and damaged rice plants (Oryza sativa) by herbivory of Tibraca limbativentris males and females. The retention index was calculated using a DB5 column.

\begin{tabular}{|c|c|c|c|c|}
\hline Compounds & $\begin{array}{l}\text { Retention } \\
\text { index }\end{array}$ & $\begin{array}{l}\text { Undamaged } \\
\text { plants }\end{array}$ & $\begin{array}{l}\text { Plants damaged by male } \\
\text { herbivore }\end{array}$ & $\begin{array}{c}\text { Plants damaged by } \\
\text { female herbivore }\end{array}$ \\
\hline (1) (E)-2-Hexenal & 838 & $30 \pm 15 a^{*}$ & $108 \pm 31 b$ & $1435 \pm 442 b$ \\
\hline (2) 6-Methyl-5-hepten-2-one & 984 & $7 \pm 2 a$ & $54 \pm 20 b$ & $78 \pm 29 b$ \\
\hline (4) $(E)$-2-Octen-1-ol ${ }^{1}$ & 1060 & $109 \pm 45 a$ & $299 \pm 112 \mathrm{ab}$ & $1860 \pm 896 b$ \\
\hline (5) $(E, E)-3,5$-Octadien-2-one & 1070 & $7 \pm 2 a$ & $42 \pm 12 b$ & $724 \pm 680 b$ \\
\hline (6) Linalool & 1099 & $50 \pm 19 a$ & $261 \pm 99 \mathrm{ab}$ & $450 \pm 173 b$ \\
\hline (9) Decanal & 1206 & $22 \pm 6 a$ & $68 \pm 15 b$ & $176 \pm 62 b$ \\
\hline (10) Benzothiazole & 1227 & $1 \pm 0.4 \mathrm{a}$ & $6 \pm 2 \mathrm{ab}$ & $20 \pm 8 b$ \\
\hline (11) 4-Ethyl acetophenone & 1263 & $7 \pm 2 a$ & $17 \pm 5 a$ & $49 \pm 17 a$ \\
\hline (12) $\beta$-Cubebene ${ }^{1}$ & 1349 & $8 \pm 2 a$ & $34 \pm 10 \mathrm{ab}$ & $91 \pm 31 b$ \\
\hline (13) Geranylacetone & 1377 & $12 \pm 3 a$ & $54 \pm 18 \mathrm{ab}$ & $88 \pm 29 b$ \\
\hline (14) $\alpha$-Curcumene & 1392 & $13 \pm 3 a$ & $75 \pm 27 \mathrm{ab}$ & $125 \pm 38 b$ \\
\hline (15) $\alpha$-Zingeberene & 1398 & $43 \pm 35 a$ & $77 \pm 31 \mathrm{ab}$ & $158 \pm 68 b$ \\
\hline
\end{tabular}

* Different letters, in the same row, indicate significantly different means by Kruskal-Wallis test and Dunn contrast, at a 5\% confidence level.

1 Tentatively identified compounds.

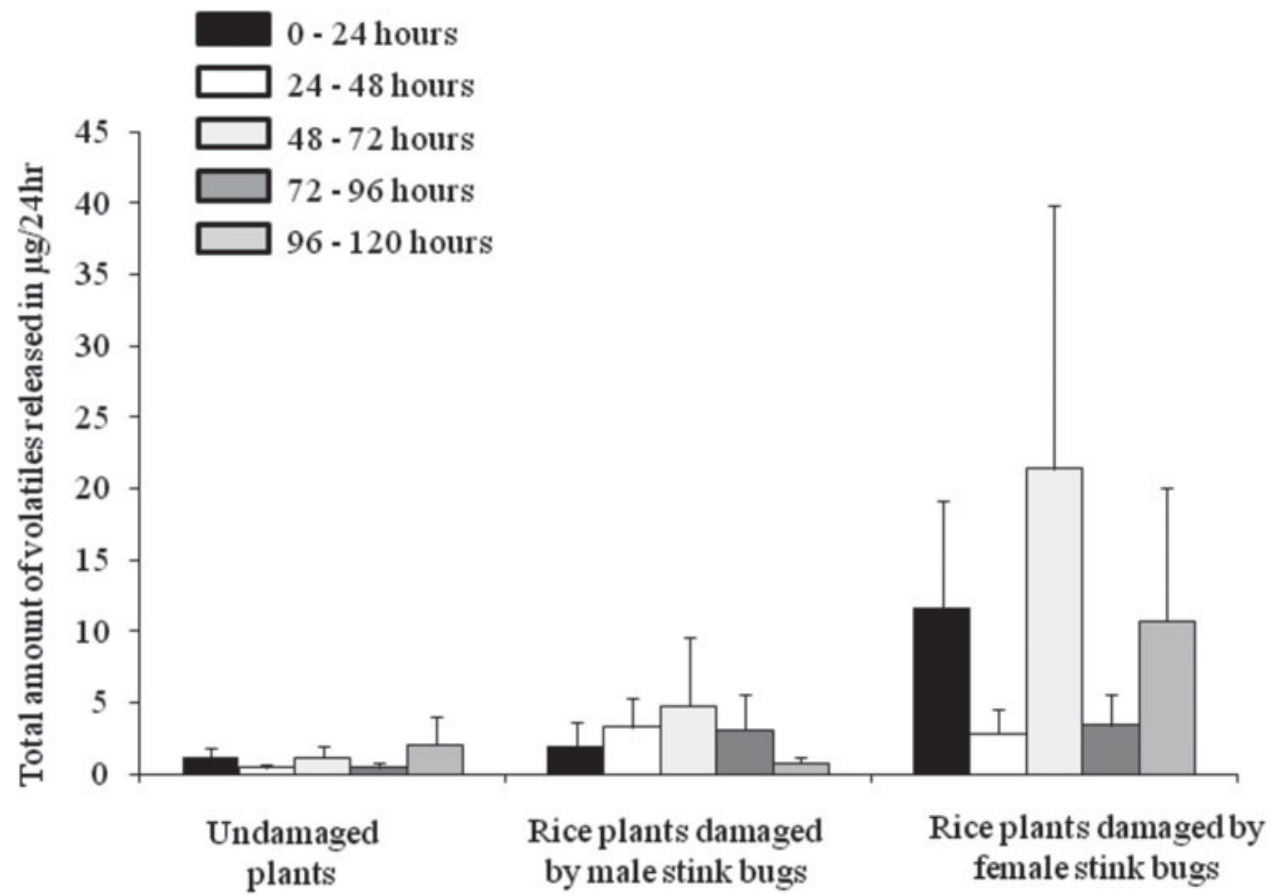

Fig. 4. Total amount of volatiles (mean + SEM) obtained from undamaged plants (control) and damaged rice plants (Oryza sativa) by herbivory of Tibraca limbativentris males and females, in each treatment in each $24 \mathrm{~h}$ period, over 5 days of aeration. There is no difference over the 5 days under the same treatment (ANODEV; $\left.\chi^{2}=0.0030 ; \mathrm{df}=2 ; P=0.95\right)$ but there is an effect among the treatments $\left(\right.$ ANODEV; $\chi^{2}=16.87$; $\mathrm{df}=2 ; P<0.001)$.

\section{Discussion}

Tibraca limbativentris females and both parasitoids responded to volatiles from undamaged plants, suggesting that these insects use information from plants to locate resources. Many insects are known to use chemical volatiles from plants as cues to find their hosts (Bruce \& Pickett, 2011; Hare, 2011; Fürstenberg-Hägg, 2013). In addition, 
T. limbativentris females did not respond to plants damaged by conspecifics, suggesting that they can avoid previously infested plants, thereby reducing competition for oviposition and feeding sites (Dicke \& Van Loon, 2000). Similar results were observed for the stink bug Lygus rugulipennis Poppius (Heteroptera: Miridae) (Frati et al., 2008). Rice stem bug males seem do not use semiochemicals from plants to distinguish damaged from undamaged plants. In general, insects of both sexes use semiochemicals from plants to find feeding and mating sites, whereas females also use them to find adequate sites for oviposition (Metcalf \& Metcalf, 1992). Some studies have shown that when the male is the sex or aggregation pheromone producer they arrive first on plants and attract females using pheromones that may combine with plant volatiles to enhance attractiveness to females (Addesso \& Mcauslane, 2009; Addesso et al., 2011; Zhang et al., 2011; Sun et al., 2012). Tibraca limbativentris males did not respond to airentrainment extract from undamaged or herbivory-damaged rice plants, but it might respond to host plant volatiles. Additional studies are necessary to confirm this hypothesis.

Telenomus podisi females preferred volatiles of undamaged plants compared to the control ( $n$-hexane) and also showed a significant preference for rice plants damaged by female over undamaged ones. The selection by natural enemies involves, basically, host location and recognition (Vinson, 1984, 1985). These two steps contain several processes where chemical, physical, vibrational, and visual cues are used to identify the appropriate host. Chemical information plays a crucial role in host location and can be produced by the plant, the herbivore or host. In general information from plants, such as herbivory or oviposition-induced volatiles and information from the herbivore are used as medium or long-range cues for locating the host (Price et al., 1980; Turlings et al., 1990; Vet \& Dicke, 1992; Dicke, 1994; Borges et al., 1998; De Moraes et al., 1998; Turlings et al., 1998; Dicke \& Van Loon, 2000; Hoballah \& Turlings, 2001; Kessler \& Baldwin, 2002; Moraes et al., 2005; Howe1 \& Jander, 2008; Moraes et al., 2008a). Plant volatiles are easily detectable, but less reliable than volatiles from the herbivore. Therefore parasitoids use plant volatiles but also other cues that are more reliable such as footprints and egg composition, as well as texture, colour, and vibrational information from eggs (Borges et al., 2003; Laumann et al., 2009, 2011; Aquino et al., 2012). Nevertheless, egg parasitoids can gain more reliable information from volatiles induced from plants by oviposition damage (Meiners \& Hilker, 1997, 2000; Colazza et al., 2004a, b; Hilker \& Meiners, 2010) or, as shown in this work, from plants damaged by females, which offer a more consistent indication that their host (eggs) will be present.

The generalist parasitoid $T$. basalis did not show a significant preference to herbivory-damaged plants in this study, but preferred undamaged plants to $n$-hexane. Although T. basalis did not exhibit a significant preference for the odour of herbivory-damaged plants, there was a tendency that the wasps preferred the odour of infested plants to the odour of non-infested plants and it preferred the odour from non-infested plants compared to hexane.

This species parasitizes eggs of different stink bug species (Colazza et al., 1999, 2009; Loch, 2000), but has not been recorded parasitizing $T$. limbativentris eggs in natural conditions; only T. podisi and T. urichi have been recorded doing so (Maciel et al., 2007; Riffel et al., 2010). This could explain why $T$. basalis did not differentiate between herbivory-damaged plants. In another study with $T$. basalis, the parasitoid did not respond to soybeans injured by another non-preferred host species, the brown stink bug, E. heros (Lopes et al., 2012).

Rice plants at the V8 physiological stage show an altered chemical profile of volatiles when damaged by male and female T. limbativentris herbivory, and this profile included common volatile plant compounds that have been identified in previous studies in different systems (Turlings et al., 1998; Rodriguez-Saona et al., 2002; Scutareanu et al., 2003; Blackmer et al., 2004; Colazza et al., 2004a; Yan \& Wang, 2006; Cheng et al., 2007; Moayeri et al., 2007; Hu et al., 2009; Gomi et al., 2010; Williams et al., 2010). In this study, we observed an induction of the indirect defence of rice plants when damaged by rice stem bug female, and several HIPVs were released in higher amount comparing to undamaged plants. A similar result was observed in a different system with rice injured by Sogatella furcifera (Hovarth) (Hemiptera: Delphacidae), in which the main compounds induced were $(E)$-2-hexenal, methyl salicylate and $\beta$-sesquiphellandrene (Gomi et al., 2010). Several other studies in different systems have shown that the relative composition of the volatiles blends provide the most important information used by insects as host-finding cues (Heil \& Ton, 2008; Moraes et al., 2009; Bruce et al., 2010; Michereff et al., 2011).

Plants damaged by $T$. limbativentris females released greater amounts of specific volatiles such as linalool, methyl salicylate, and sesquiterpenes than undamaged plants. Similar results were observed in soybean plants injured by both sexes of E. heros (Moraes et al., 2005). The differences observed in the chemical compounds released following plant damage by conspecifics of different genders could be associated with the time spent by insects feeding on the plants or with the volume of saliva production (Moraes et al., 2005). Females could require greater amounts of resources to guarantee the viability of their descendants, so they should feed for longer periods than males, and consequently cause greater damage to plants. Further studies are necessary to confirm this hypothesis.

Three substances that were identified as HIPVs, nonanal, decanal and the ketone 6-methyl-5-hepten-2-one are present in the blend of defensive compounds of T. limbativentris (Borges et al., 2006; Moraes et al., 2008b). We thus cannot determine whether these compounds are from plants or insects, but since other insect defensive compound of the rice stem bug, such as tridecane, which is the major and most common in stink bugs (Borges et al., 2006; Moraes et al., 2008b; Oliveira, 2013), was not present in the plant extract, we believe the increase of these volatiles was related to the herbivory, as shown for other HIPVs observed in this work.

The results of this study showed that female T. limbativentris can recognize and prefer rice plants not infested by conspecifics, and also that the indirect defence of rice plants was induced. These results offer additional support for studies using plant semiochemicals to manage natural enemies and pests in field conditions. A further work by using CG-EAD (Coupled Gas Chromatography - Electroantennographic Detection) technique will be conducted to better understand T. limbativentris antennal perception to volatile plant differences.

However, there are still a large number of questions to answer before field studies are undertaken. For example, studies are needed to understand the importance of individual and mixed plant semiochemicals for natural enemy response, and to determine whether induced rice plants can repel $T$. limbativentris females in the field. Such a strategy could potentially be applied to minimize pest populations in rice crops. 


\section{References}

Addesso, K.M. \& Mcauslane, H.J. (2009) Pepper weevil attraction to volatiles from host and nonhost plants. Environmental Entomology 38, 216-224.

Addesso, K.M., Mcauslane, H.J. \& Alborn, H.T. (2011) Attraction of pepper weevil to volatiles from damaged pepper plants. Entomologia Experimentalis et Applicata 91, 1-11.

Arimura, G., Matsui, K. \& Takabayashi, J. (2009) Chemical and molecular ecology of herbivore-induced plant volatiles: proximate factors and their ultimate functions. Plant and Cell Physiology 50, 911-923.

Aquino, M.F.S., Dias, A.M., Borges, M., Moraes, M.C.B. \& Laumann, R.A. (2012) Influence of visual cues on hostsearching and learning behaviour of the egg parasitoids Telenomus podisi and Trissolcus basalis. Entomologia Experimentalis et Applicata 145, 162-174.

Blackmer, J.L., Rodriguez-Saona, C., Byers, J.A., Shope, K.L. \& Smith, J.P. (2004) Behavioural response of Lygus hesperus to conspecifics and headspace volatiles of alfalfa in a y-tube olfactometer. Journal of Chemical Ecology 30, 1547-1564.

Blassioli-Moraes, M.C., Borges, M. \& Laumann, R.A. (2013) The application of chemical cues in Arthropod Pest management for arable crops. pp. 225-239 in Wajnberg, E. \& Colazza, S. (Eds) Chemical ecology of insect parasitoids. West Sussex-UK, Wiley-Blackwell.

Borges, M., Schmidt, F.G.V., Sujii, E.R., Medeiros, M.A., Mori, K., Zarbin, P.H.G. \& Ferreira, J.T.B. (1998) Field responses of stink bugs to the natural and synthetic pheromone of the Neotropical brown stink bug, Euschistus heros (Heteroptera : Pentatomidae). Physiological Entomology 23, 202-207.

Borges, M., Colazza, S., Ramirez-Lucas, P., Chauhan, K.R., Moraes, M.C.B. \& Aldrich, J.R. (2003) Kairomonal effect of walking traces from Euschistus heros (Heteroptera: Pentatomidae) on two strains of Telenomus podisi (Hymenoptera: Pentatomidae). Physiological Entomology 28, 349-355.

Borges, M., Birkett, M., Aldrich, J.R., Oliver, J.E., Chiba, M., Murata, Y., Laumann, R.A., Barrigossi, J.A., Pickett, J.A. \& Moraes, M.C.B. (2006) Sex attractant pheromone from the rice stalk stink bug, Tibraca limbativentris Stal. Journal of Chemical Ecology 32, 2749-2761.

Bruce, T.J.A. \& Pickett, J.A. (2011) Perception of plant volatile blends by herbivorous insects - finding the right mix. Phytochemistry 72, 1605-1611.

Bruce, T.J.A., Midega, C.A.O., Birkett, M.A., Pickett, J.A. \& Khan, Z.R. (2010) Is quality more important than quantity? Insect behavioural responses to changes in a volatile blend after stemborer oviposition on an African grass. Biology Letters 6, 314-317.

Cheng, A.X., Xiang, C.Y., Li, J.X., Yang, C.Q., Hu, W.L., Wang, L. J., Lou, Y.G. \& Chen, X.Y. (2007) The rice (E)- $\beta$-caryophyllene synthase (OsTPS3) accounts for the major inducible volatile sesquiterpenes. Phytochemistry 68, 1632-1641.

Colazza, S., Salerno, G. \& Wajnberg, E. (1999) Volatile and contact chemicals released by Nezara viridula (Heteroptera: Pentatomidae) have a kairomonal effect on the egg parasitoid Trissolcus basalis (Hymenoptera: Scelionidae). Biological Control 16, 310-317.

Colazza, S., Mcelfresh, J.S. \& Millar, J.G. (2004a) Identification of volatile synomones, induced by Nezara viridula feeding and oviposition on bean spp., that attracts the egg parasitoid Trissolcus basalis. Journal of Chemical Ecology 30, 945-964.
Colazza, S., Fucarino, A., Peri, E., Salerno, G., Conti, E. \& Bin, F. (2004b) Insect oviposition induces volatile emission in herbaceous plants that attracts egg parasitoids. Journal of Experimental Biology 207, 47-53.

Colazza, S., Bue, M.L., Giudice, D.L. \& Peri, E. (2009) The response of Trissolcus basalis to footprint contact kairomones from Nezara viridula females is mediated by leaf epicuticular waxes. Naturwissenschaften 96, 975-981.

Conti, E. \& Colazza, S. (2012) Chemical Ecology of Egg Parasitoids Associated with True Bugs. Psyche 2012, 1-11.

Cook, S.M., Khan, Z.R. \& Pickett, J.A. (2007) The use of push-pull strategies in Integrated Pest Management. Annual Review of Entomology 52, 375-400.

D'Alessandro, M. \& Turlings, T.C.J. (2005) In situ modification of herbivore-induced plant odors: a novel approach to study the attractiveness of volatiles organic compound to parasitic wasps. Chemical Senses 30, 739-753.

De Moraes, C.M., Lewis, W.J., Pare, P.W., Alborn, H.T. \& Tumlinson, J.H. (1998) Herbivore-infested plants selectively attract parasitoids. Nature 393, 570-573.

De Moraes, C.M., Mescher, M.C. \& Tumlinson, J.H. (2001) Caterpillar induced nocturnal plant volatiles repel conspecific females. Nature 40, 577-580.

Dicke, M. (1994) Local and systemic production of volatile herbivore-induced terpenoids - their role in plant-carnivore mutualism. Journal of Plant Physiology 143, 465-472.

Dicke, M. (1999) Are herbivore-induced plant volatiles reliable indicators of herbivore identity to foraging carnivorous arthropods? Entomologia Experimentalis et Applicata 91, 131-142.

Dicke, M. \& Van Loon, J.J.A. (2000) Multitrophic effects of herbivore-induced plant volatile in an evolutionary context. Entomologia Experimentalis et Applicata 97, 237-249.

Dudareva, N., Negre, F., Nagegowda, D.A. \& Orlova, I. (2009) Plant volatiles: recent advances and future perspectives Critical. Reviews in Plant Sciences 25, 417-440.

Frati, F., Salerno, G., Conti, E. \& Bin, F. (2008) Role of the plant conspecific complex in host location and intra-specific communication of Lygus rugulipennis. Physiological Entomology 33, 129-137.

Fürstenberg-Hägg, J., Zagrobelny, M. \& Bak, S. (2013) Plant defense against insect herbivores. International Journal of Molecular Sciences 14, 10242-10297.

Gomi, K., Satoh, M., Ozawa, R., Shinonaga, Y., Sanada, S., Sasaki, K., Matsumura, M., Ohashi, Y., Kanno, H., Akimitsu, K. \& Takabayashi, J. (2010) Role of hydroperoxide lyase in white-backed planthopper (Sogatella furcifera Horváth)-induced resistance to bacterial blight in rice, Oryza sativa L. Plant Journal 61, 46-57.

Halitschke, R., Stenberg, J.A., Kessler, D., Kessler, A. \& Baldwin, I.T. (2008) Shared signals - 'alarm calls' from plants increase apparency to herbivores and their enemies in nature. Ecology Letters 11, 24-34.

Hare, J.D. (2011) Ecological role of volatiles produced by plants in response to damage by herbivorous insects. Annual Review of Entomology 56, 161-180.

Heil, M. (2010) Plastic defence expression in plants. Ecology and Evolution 24, 555-569.

Heil, M. \& Ton, J. (2008) Long-distance signalling in plant defence. Trends in Plant Science 13, 264-272.

Hilker, M. \& Meiners, T. (2010) How do plants 'notice' attack by herbivorous arthropods? Biological Reviews 85, 267-280.

Hoballah, M.E.F. \& Turlings, T.C.J. (2001) Experimental evidence that plants under caterpillar attack may benefit 
from attracting parasitoids. Evolutionary Ecology Research 3, 553-565.

Howe, G.A. \& Jander, G. (2008) Plant immunity to insect herbivores. Annual Review of Plant Biology 59, 41-66.

Hu, Z., Shen, Y., Shen, F., Luo, Y. \& Su, X. (2009) Evidence for the signaling role of methyl jasmonate, methyl salicylate and benzothiazole between poplar (Populus simonii $\mathrm{X}$ P. pyramidalis 'Opera 8277') cuttings. Trees 23, 1003-1011.

James, D.G. (2003) Field evaluation of herbivore-induced plant volatiles as attractants for beneficial insects: methyl salicylate and the green lacewing, Chrysopa nigricornis. Journal of Chemical Ecology 29, 1601-1609.

James, D.G. (2005) Further field evaluation of synthetic herbivoreinduced plant volatiles as attractants for beneficial insects. Journal of Chemical Ecology 31, 481-495.

Kaplan, I. (2012) Attracting carnivorous arthropods with plant volatiles: the future of biocontrol or playing with fire? Biological Control 60, 77-89.

Kessler, A. \& Baldwin, I.T. (2001) Defensive function of herbivore-induced plant volatile emissions in nature. Science 291, 2141-2144.

Kessler, A. \& Baldwin, I.T. (2002) Plant responses to insect herbivory: the emerging molecular analysis. Annual Review of Plant Biology 53, 299-328.

Kessler, A., Halitschke, R. \& Baldwin, I.T. (2004) Silencing the jasmonate cascade: induced plant defenses and insect populations. Science 35, 665-668.

Laumann, R.A., Aquino, M.F.S., Moraes, M.C.B., Pareja, M. \& Borges, M. (2009) Response to egg parasitoids Trissolus basalis and Telenomus podisi to compounds from defensive secretions of stink bugs. Journal of Chemical Ecology 35, 8-19.

Laumann, R.A., Cokl, A., Lopes, A.P.S., Ferreira, J.B.C., Moraes, M.C.B. \& Borges, M. (2011) Silent singers are not safe: selective response of a parasitoid to substrate-borne vibratory signals of stink bugs. Animal Behaviour 82, 11751183.

Lin, C., Shen, B., Xu, Z., Köllner, T.G., Degenhard, J. \& Dooner, H. (2008) Characterization of monoterpene synthase gene tps 26, the ortholog of a gene induced by insect herbivory in maize. Plant Physiology 146, 940-951.

Loch, A.D. (2000) Abundance, distribution, and availability of Trissolcus basalis (Wollaston) (Hymenoptera: Scelionidae) hosts in a soybean agricultural system in southeastern Queensland. Biological Control 18, 120-135.

Lopes, A.P.S., Diniz, I.R., Moraes, M.C.B., Borges, M. \& Laumann, R.A. (2012) Defesas induzidas por herbivoria e interações específicas no sistema tritrófico soja-percevejosparasitoides de ovos. Pesquisa Agropecuária Brasileira 47, 875-878.

Maciel, A.A.S., Lemos, R.N.S., Souza, J.R., Costa, V.A., Barrigossi, J.A.F. \& Chagas, E.F. (2007) Parasitismo de ovos de Tibraca limbativentris Stal (Hemiptera: Pentatomidae) na cultura do arroz no Maranhão. Neotropical Entomology 36, 616-618.

Martins, J.F.S., Barrigossi, J.A.F., Oliveira, J.V. \& Cunha, U.S. (2009) Situação do manejo integrado de insetos-praga na cultura do arroz no Brasil. Pelotas, Embrapa Clima Temperado. (Documentos, 290).

Mazid, M., Khan, T.A. \& Mohammad, F. (2011) Role of secondary metabolites in defence mechanisms of plants. Biology and Medicine 3, 232-249.

Meiners, T. \& Hilker, M. (1997) Host location in Oomyzus gallerucae (Hymenoptera: Eulophidae), an egg parasitoid of the elm leaf beetle Xanthogaleruca luteola (Coleoptera: Chrysomelidae). Oecologia 112, 87-93.

Meiners, T. \& Hilker, M. (2000) Induction of plant synomones by oviposition of a phytophagus insect. Journal of Chemical Ecology 26, 221-232.

Metcalf, R.L. \& Metcalf, E.R. (1992) Plant Kairomones in Insect Ecology and Control. New York, Chapman \& Hall.

Michereff, M.F.F., Laumann, R.A., Borges, M., Michereff-Filho, M., Diniz, I.R., Neto, A.L.F. \& Moraes, M.C.B. (2011) Volatiles mediating a plantherbivore-natural enemy interaction in resistant and susceptible soybean cultivars. Journal of Chemical Ecology 37, 273-285.

Moayeri, H.R.S., Ashouri, A., Poll, L. \& Enkegaard, A. (2007) Olfactory response of a predatory mirid to herbivore induced plant volatiles: multiple herbivory vs. single herbivory. Journal of Applied Entomology 131, 326-332.

Moraes, M.C.B., Laumann, R., Sujii, E.R., Pires, C. \& Borges, M. (2005) Induced volatiles in soybean and pigeon pea plants artificially infested with the neotropical brow stink bug, Euschistus heros, and their effect on the egg parasitoid, Telenomus podisi. Entomologia Experimentalis et Applicata 115, 227-237.

Moraes, M.C.B., Birkett, M.A., Gordon-Weeks, R., Smart, L.E., Martin, J.L., Pye, B.J., Bromilow, R. \& Pickett, J.A. (2008a) Cis-Jasmone induces accumulation of defence compounds in wheat, Triticum aestivum. Phytochemistry 69, 9-17.

Moraes, M.C.B., Pareja, M. \& Laumann, R.A. \& Borges, M. (2008b) The chemical volatiles (Semiochemicals) produced by neotropical stink bugs (Hemiptera: Pentatomidae). Neotropical Entomology 37, 489-505.

Moraes, M.C.B., Laumann, R.A., Pareja, M., Sereno, F.T.P.S., Michereff, M.F.F., Birkett, M.A., Pickett, J.A. \& Borges, M. (2009) Attraction of the stink bug egg parasitoid Telenomus podisi to defence signals from soybean activated by treatment with cis-jasmone. Entomologia Experimentalis et Applicata 131, 178-188.

Oliveira, M.W.M., Borges, M., Andrade, C.K.Z., Laumann, R.A., José Barrigossi, J.A.F., Blassioli-Moraes, M.C. (2013) Zingiberenol, (1S,4R,1'S)-4-(1',5'-Dimethylhex-4'-enyl)-1methylcyclohex-2-en-1-ol, identified as the sex pheromone produced by males of the rice stink bug Oebalus poecilus (Heteroptera: Pentatomidae). Journal of Agricultural and Food Chemistry 61, 7777-7785.

Price, P.W., Bouton, C., Gross, P., McPheron, B.A., Thompson, J. N. \& Weis, A.E. (1980) Interactions among three trophic levels: influence of plants on interactions between insect herbivores and natural enemies. Annual review of Ecology and Systematics 11, 41-65.

R Development Core Team (2012) R: A Language and Environment for Statistical Computing. Vienna, Austria: R Foundation for Statistical Computing.

Rasmann, S. \& Turlings, T.C.J. (2008) First insights into specificity of belowground tritrophic interactions. Oikos 117, 362-369.

Riffel, C.T., Prando, H.F. \& Boff, M.I.C. (2010) First record of Telenomus podisi (Ashmead) and Trissolcus urichi (Crawford) (Hymenoptera: Scelionidae) parasitizing eggs of the rice stern bug, Tibraca limbativentris (Stal) (Hemiptera: Pentatomidae), in Santa Catarina, Brazil. Neotropical Entomology 39, 447-448.

Rodriguez-Saona, C., Crafts-Brandner, S.J., Williams, L. \& Paré, P.W. (2002) Lygus hesperus feeding and salivary gland 
extracts induce volatile emissions in plants. Journal of Chemical Ecology 28, 1733-1747.

Scutareanu, P., Bruin, J., Posthumus, M.A. \& Drukker, B. (2003) Constitutive and herbivore-induced volatiles in pear, alder and hawthorn trees. Chemoecology 13, 63-74.

SOSBAI, Sociedade Sul-Brasileira de Arroz Irrigado (2012) Arroz Irrigado: Recomendações técnicas da pesquisa para o Sul do Brasil. Porto Alegre, Sosbai.

Sun, X.L., Wang, G.C., Gao, Y. \& Chen, Z.M. (2012) Screening and field evaluation of synthetic volatile blends attractive to adults of the tea weevil, Myllocerinus aurolineatus. Chemoecology 22, 229-237.

Turlings, T.C.J., Tumlinson, J.H. \& Lewis, W.J. (1990) Exploitation of herbivore-induced plant odors by host-seeking parasitic wasps. Science 250, 1251-1253.

Turlings, T.C.J., Lengwiler, U.B., Bernasconi, M.L. \& Wechsler, D. (1998) Timing of induced volatile emissions in maize seedlings. Planta 207, 146-152.

Vet, L.E.M. \& Dicke, M. (1992) Ecology infochemical use by natural enemies in a tritrophic context. Annual review of Entomology 37, 141-72.
Vinson, S.B. (1984) Parasitoid-host relationship: chemical ecology of insects. pp. 205-233 in Bell, W.J. \& Cardé, R.T. (Eds) The Chemical Ecology of Insects. New York: Chapman \& Hall.

Vinson, S.B. (1985) The behaviour of parasitoids, pp. 417-469 in Kerkut, E.A. \& Gilbert, L.I. (Eds.), Comprehensive insect physiology, biochemistry and pharmacology. New York, Pergamon Press.

Yan, Z.G. \& Wang, C.Z. (2006) Identification of Mythmna separata-induced maize volatile synomones that attract the parasitoid Campoletis chlorideae. Journal of Applied Entomology 130, 213-219.

Williams, L., Blackmer, J.L., Rodriguez-Saona, C. \& Zhu, S. (2010) Plant volatiles influence electrophysiological and behavioral responses of Lygus hesperus. Journal of Chemical Ecology 36, 467-478.

Zhang, Q.H., Ma, J.H., Yang, Q.Q., Byers, J.A., Klein, M.G., Zhao, F.Y. \& Luo, Y.Q. (2011) Olfactory and visual responses of the long-legged chafer Hoplia spectabilis Medvedev (Coleoptera: Scarabaeidae) in Qinghai Province, China. Pest Management Science 67, 162-169. 